\title{
Effects of newborn characteristics and length of colostrum feeding period on passive immune transfer in goat kids
}

\author{
N. Castro, ${ }^{*}$ J. Capote, $†$ A. Morales-delaNuez, ${ }^{*}$ C. Rodríguez, ${ }^{*}$ and A. Argüello*1 \\ ${ }^{*}$ Department of Animal Science, Las Palmas de Gran Canaria University, Arucas 35413, Spain \\ †Canary Agronomic Science Institute, La Laguna, Tenerife 38200, Spain
}

\begin{abstract}
Majorera goat kids $(\mathrm{n}=200)$ were used to evaluate the effects of litter size, birth body weight, sex, and suckling duration on serum IgG concentrations. Kids were assigned to 1 of 3 experimental groups: litter size and sex were equally distributed in each group. In the first group, kids $(\mathrm{n}=67)$ stayed with their dams for 24 $\mathrm{h}$; in the second group, kids $(\mathrm{n}=66)$ stayed with their dams for $48 \mathrm{~h}$; and in the third group, kids $(\mathrm{n}=67)$ stayed with their dams for $120 \mathrm{~h}$. Blood samples were obtained every $24 \mathrm{~h}$ for $5 \mathrm{~d}$, and serum IgG concentration was measured using radial immunodiffusion. In litter sizes of 1 to 2 kids, IgG blood serum concentration was significantly higher $(18.30 \pm 5.40 \mathrm{mg} / \mathrm{mL})$ than in litters of 3 kids $(9.85 \pm 4.23 \mathrm{mg} / \mathrm{mL})$. Kid sex did not affect IgG blood serum concentrations. Suckling duration did not affect kid serum IgG concentrations. In conclusion, kids with low birth body weight $(<2.8$ $\mathrm{kg}$ ) or from litters of 3 may need special attention. If newborn goat kids are allowed to suckle colostrum for at least $24 \mathrm{~h}$ from their dams, this seems to be sufficient time to ingest enough IgG from colostrum to achieve an adequate serum $\operatorname{Ig} G$ concentration and passive immune protection to avoid failure of passive immune transfer.
\end{abstract} Key words: goat kid, birth weight, litter size, immune passive transfer

\section{INTRODUCTION}

Ruminant placenta impedes the transfer of Ig from the dam to the fetus. Constant et al. (1994) asserted that goat kids are agammaglobulinemic at birth; however, Guerrault (1990), Rabbani et al. (1990), and Sherman et al. (1990) are all of the opinion that low serum IgG concentrations are present at birth. Consequently, the consumption of colostrum by the progeny of these species (cow, sheep, and goat) has a fundamental role in the acquisition of passive immunity (Lascelles, 1979).

Received May 27, 2008.

Accepted November 21, 2008.

${ }^{1}$ Corresponding author: aarguello@dpat.ulpgc.es
Some factors may directly affect the passive immune status of young ruminants, such as birth BW, litter size, sex, suckling duration, colostrum quantity, colostrum quality, and delay in colostrum feeding. Many of these factors have been previously studied in goat kids (Argüello et al., 2004; Castro et al., 2005, 2007), whereas others, such as birth BW, litter size, sex, and suckling duration have not yet been closely examined.

Chen et al. (1999) reported a peak blood serum IgG concentration of $33 \mathrm{mg} / \mathrm{mL} 24 \mathrm{~h}$ after birth following ingestion of colostrum. O'Brien and Sherman (1993) have defined failure of passive transfer (FPT) in the goat kid as a serum IgG concentration of $<12 \mathrm{mg} / \mathrm{mL}$ using a spectrophotometric zinc sulfate turbidity assay. In addition, Argüello et al. (2004) found an IgG blood concentration of $<5 \mathrm{mg} / \mathrm{mL}$ at $48 \mathrm{~h}$ postpartum in kids dying during the first month of life.

Castro et al. (2007) reported no significant effects of birth BW on IgG blood serum concentrations in kids, but there was a tendency for IgG concentrations to increase when the birth BW was between 2.5 and $3.2 \mathrm{~kg}$. Chen et al. (1999) observed lower concentrations of IgG in the blood of single-born kids than for twins. O'Brien and Sherman (1993) and Chen et al. (1999) observed no significant relationship between kid sex and serum IgG concentrations after the ingestion of colostrum.

Previous research (Argüello et al., 2004; Castro et al., 2005, 2007) recommended the removal of kids from their dam at birth in dairy goat herds for 2 main reasons: to prevent a strong mother-kid link (Ramírez et al., 1996) and to reduce the risk of viral transmission by colostrum of caprine arthritis encephalitis virus (Guerrault, 1990). However, some farmers are still reluctant to remove kids at birth and allow the kids to stay with their dams for a few days postpartum to permit prolonged ingestion of colostrum. It is not clear how much time is necessary for goat kids to stay with their dams to provide sufficient passive transfer of immunity. The aim of the present study was to evaluate the effect of litter size, birth BW, sex, and duration of colostrum feeding on IgG blood serum concentrations during the first $5 \mathrm{~d}$ of life. 
Table 1. Kid distribution in the different experimental groups

\begin{tabular}{|c|c|c|c|c|c|c|c|}
\hline \multirow{2}{*}{$\begin{array}{l}\text { Colostrum } \\
\text { suckling, d }\end{array}$} & \multicolumn{2}{|c|}{ Single kid } & \multicolumn{2}{|c|}{ Twins } & \multicolumn{2}{|c|}{ Triplets } & \multirow[b]{2}{*}{ Total kids } \\
\hline & Male & Female & Male & Female & Male & Female & \\
\hline 1 & 12 & 11 & 11 & 11 & 10 & 12 & 67 \\
\hline 2 & 11 & 11 & 11 & 11 & 11 & 11 & 66 \\
\hline 3 & 12 & 10 & 11 & 11 & 11 & 12 & 67 \\
\hline
\end{tabular}

\section{MATERIALS AND METHODS}

This study was carried out at the experimental farm of the Faculty of Veterinary Studies of the University of Las Palmas de Gran Canaria (Gran Canaria, Spain). The experimental procedures were approved by the Las Palmas de Gran Canaria University ethical committee. Majorera kids $(\mathrm{n}=200)$ were born from permanently sheltered and intensively fed doe goats. Goats were supervised from 0800 to $2300 \mathrm{~h}$ during the parturition season (from January to December). Only kids born during directly supervised parturitions were included in the study. Two hundred newborn Majorera kids were allocated in 3 equilibrated groups according to litter size $(1,2$, or 3 kids) and sex (male or female) to which the experimental treatments were randomly assigned immediately after birth (Table 1). In the first group, kids $(\mathrm{n}=67)$ remained with their dams for $1 \mathrm{~d}$; in the second group, kids $(\mathrm{n}=66)$ stayed with their dams for $2 \mathrm{~d}$; and in the third group, kids $(\mathrm{n}=67)$ stayed with their dams for 5 d. Kids were weighed, ear tagged, and navels were disinfected after birth.

Blood samples $(3 \mathrm{~mL})$ were obtained from each kid at birth by jugular venipuncture. Sampling was repeated at 24-h intervals until $120 \mathrm{~h}$ of age. Blood was centrifuged at $1,300 \times g$ for $5 \mathrm{~min}$ at $4^{\circ} \mathrm{C}$. Serum was divided into 2 aliquots and stored at $-20^{\circ} \mathrm{C}$ until $\mathrm{IgG}$ analysis. Serum IgG concentration was determined using the radial immunodiffusion method described by Mancini et al. (1965) modified by Castro et al. (2005).

A general linear model PROC MIXED procedure was performed to evaluate the effects of litter size, birth BW, sex, and suckling duration on IgG blood serum concentration and on interactions between the main variation factors. After that, a Tukey's test was performed $(P<0.05)$. Statistical analysis was performed using SAS software (v. 9.0, SAS Institute Inc., Cary, $\mathrm{NC})$.

\section{RESULTS AND DISCUSSION}

The IgG blood serum concentration through the first $5 \mathrm{~d}$ of life according to litter size is shown in Table 2. Mean IgG blood serum concentrations for kids of 1 - and 2-kid litters ranged from 15.5 to $23.1 \mathrm{mg} / \mathrm{mL}$, which was greater $(P<0.05)$ than those of kids from 3-kid litters, which had values ranging from 6.2 to $16.3 \mathrm{mg} /$ $\mathrm{mL}$. The $\mathrm{IgG}$ concentrations in kids from litter sizes of 1 and 2 kids were closer to that reported by Argüello et al. (2004) for the same breed with similar management, and were well above the FPT IgG serum concentration threshold. On the contrary, kids from litters of 3 kids showed IgG concentrations indicative of FPT at 1, 3, 4, and 5 d post-birth (O'Brien and Sherman, 1993). These IgG concentration differences between litter sizes 1 or 2 and 3 may arise for 2 main reasons: low colostrum production or low colostrum intake. Low colostrum production most likely affects nondairy breeds; the Majorera breed usually produces more than $2 \mathrm{~L}$ of colostrum in the first $24 \mathrm{~h}$ postpartum (A. Argüello, unpublished data) with a mean IgG blood serum concentration of $35 \mathrm{mg} / \mathrm{mL}$ (Argüello et al., 2006). The total $\mathrm{IgG}$ produced during $24 \mathrm{~h}$ is thus approximately 70 g. Castro et al. (2005) reported that $4 \mathrm{~g}$ of $\mathrm{IgG}$ per $\mathrm{kg}$ of BW was sufficient to avoid FPT. Based on these data, $2 \mathrm{~L}$ of colostrum with an IgG blood serum concentration of $35 \mathrm{mg} / \mathrm{mL}$ would be sufficient for 17.5 $\mathrm{kg}$ of neonate BW. The second hypothesis was more suitable to explain the results shown in Table 1 . In addition, Castro et al. (2005) reported low IgG blood concentrations in animals in 3-kid litters because access to teats was more difficult for them than for kids in 1or 2-kid litters. Ramírez et al. (1998) also showed that twin kids of Murciano-Granadina breed took longer for first stand up than single kids. A third possibility is that kids from a litter of 3 usually present lower birth BW than kids from litter sizes of 1 or 2 (Fabelo et al., 1992), which might limit gut size and thus feed intake capacity, lowering the amount of ingested colostrum. Bekele et al. (1992) did not find differences between single and twin lambs from the Ethiopian Menz breed. These results are similar to those shown in Table 2 for single or twin kids, but differences were found with triplets.

Table 2 shows the mean IgG blood serum concentrations dependent on birth BW. Kids with a birth BW ranging from 2.8 to $3.3 \mathrm{~kg}$ and 3.3 to $4.2 \mathrm{~kg}$ presented significantly higher IgG blood serum concentrations throughout the experiment than kids with birth BW between 1.7 to $2.8 \mathrm{~kg}$. Immunoglobulin $\mathrm{G}$ blood serum 
Table 2. Immunoglobulin $\mathrm{G}$ in blood serum $(\mathrm{mg} / \mathrm{mL}$, least squares means) in kids

\begin{tabular}{|c|c|c|c|c|c|c|}
\hline \multirow[b]{2}{*}{ Item } & \multicolumn{5}{|c|}{ Age, $\mathrm{h}$} & \multirow[b]{2}{*}{ SEM } \\
\hline & 24 & 48 & 72 & 96 & 120 & \\
\hline \multicolumn{7}{|l|}{ Litter size } \\
\hline Single & $23.1^{\mathrm{a}, \mathrm{x}}$ & $20.6^{\mathrm{a}, \mathrm{x}}$ & $16.5^{\mathrm{b}, \mathrm{x}}$ & $17.3^{\mathrm{b}, \mathrm{x}}$ & $18.3^{\mathrm{b}, \mathrm{x}}$ & 1.5 \\
\hline Twins & $18.5^{\mathrm{a}, \mathrm{x}}$ & $19.2^{\mathrm{a}, \mathrm{x}}$ & $17.5^{\mathrm{a}, \mathrm{x}}$ & $16.4^{\mathrm{ab}, \mathrm{x}}$ & $15.5^{\mathrm{b}, \mathrm{x}}$ & 0.9 \\
\hline Triplets & $10.3^{\mathrm{a}, \mathrm{y}}$ & $16.3^{\mathrm{b}, \mathrm{y}}$ & $8.7^{\mathrm{a}, \mathrm{y}}$ & $7.8^{\text {ac,y }}$ & $6.2^{\mathrm{c}, \mathrm{y}}$ & 1.9 \\
\hline \multicolumn{7}{|c|}{ Birth $\mathrm{BW}$ range, $\mathrm{kg}$} \\
\hline 1.7 to 2.78 & $13.1^{\mathrm{a}, \mathrm{x}}$ & $15.3^{\mathrm{b}, \mathrm{x}}$ & $12.3^{\mathrm{a}, \mathrm{x}}$ & $11.8^{\mathrm{a}, \mathrm{x}}$ & $10.7^{\mathrm{a}, \mathrm{x}}$ & 1.2 \\
\hline 2.8 to 3.2 & $22.4^{\mathrm{a}, \mathrm{y}}$ & $21.7^{\mathrm{a}, \mathrm{y}}$ & $17.8^{\mathrm{b}, \mathrm{y}}$ & $17.3^{\mathrm{b}, \mathrm{y}}$ & $17.4^{\mathrm{b}, \mathrm{y}}$ & 1.2 \\
\hline 3.3 to 4.2 & $20.0^{\mathrm{a}, \mathrm{y}}$ & $20.5^{\mathrm{a}, \mathrm{y}}$ & $18.3^{\text {ab,y }}$ & $17.5^{\text {ab,y }}$ & $16.7^{\mathrm{b}, \mathrm{y}}$ & 1.2 \\
\hline
\end{tabular}

${ }^{\mathrm{a}-\mathrm{c}}$ Means within a row with different superscripts differ $(P<0.05)$.

${ }^{\mathrm{x}, \mathrm{y}}$ Means within a column and item with different superscripts differ $(P<0.05)$.

concentrations in the 2 highest birth BW groups ranged from 22.4 to $16.7 \mathrm{mg} / \mathrm{mL}$ over the FPT levels described by O'Brien and Sherman (1993). However, kids with birth BW ranging from 1.8 to $2.8 \mathrm{~kg}$ had $\mathrm{IgG}$ blood serum concentrations lower than those described by O'Brien and Sherman (1993) at d 4 and 5 postpartum. Argüello et al. (2004) reported no significant effect of birth BW on IgG blood serum concentrations working with only 60 goat kids; although there were no differences, there was a tendency for IgG concentrations to increase as birth BW increased. Conversely, Bekele et al. (1992) failed to find differences in IgG blood serum concentrations for lambs with birth BW ranging from 1.0 to $1.5 \mathrm{~kg}$ and lambs with birth BW over $3.0 \mathrm{~kg}$. Ramírez et al. (1998) observed significant differences between higher and lower birth BW on goat kids upon initial attempts to stand and first successful standing; this behavior may help to explain the IgG value differences observed in Table 2.

Connecting results from litter size and birth BW, $100 \%$ of single kids presented birth BW $>2.7 \mathrm{~kg}, 90 \%$ of twin kids presented birth $\mathrm{BW}>2.7 \mathrm{~kg}$, but only $20 \%$ of triplets kids presented birth BW $>2.7 \mathrm{~kg}$. These results corroborate the relationship between litter size and birth BW and might explain why triplet kids presented lower IgG blood serum concentrations. In contrast to previous hypotheses, Bekele et al. (1992) did not find differences in blood $\operatorname{IgG}$ by lamb birth weight, but reported that IgG concentration in blood serum was higher in heavier lambs (>3.0 kg of BW; $41 \mathrm{mg} /$ $\mathrm{mL}$ ) than in lighter weight lambs (1 to $1.5 \mathrm{~kg}$ of $\mathrm{BW}$; $31 \mathrm{mg} / \mathrm{mL}$ ). Because of previous results, farmers should pay special attention to kids with birth BW lower than $2.8 \mathrm{~kg}$.

With regards to kid sex, there were no differences between male and female kid IgG blood serum concentration, the IgG concentration in blood serum averaging 18.1, 18.8, 16.1, 15.2, and $14.8 \mathrm{mg} / \mathrm{mL}$ (SEM, 1.23 ) for $24,48,72,96$, and $120 \mathrm{~h}$ of life, respectively. Chen et al. (1999) and Argüello (2000) did not observe differences between sexes in Nubian or Majorera kids, but O'Brien and Sherman (1993) observed that males tend to present a higher IgG blood serum concentration than females. The reason for these differences might be different managements of colostrum feeding periods; thus, in Chen et al. (1999) and Argüello (2000) male and female kids received the same colostrum, whereas in O'Brien and Sherman (1993) female kids were fed with pasteurized colostrum. Moreover, Argüello et al. (2003) reported that colostrum pasteurization reduces IgG by approximately $20 \%$.

Table 3 shows the effect of suckling duration on mean IgG blood serum concentration. No differences were observed between kids left for 1,2 , or $5 \mathrm{~d}$ with their dams; the IgG blood serum concentrations for all experimental groups ranged from 14.1 to $19.9 \mathrm{mg} / \mathrm{mL}$. Immunoglobulin $\mathrm{G}$ serum concentrations for the kids were higher than the $12 \mathrm{mg} / \mathrm{mL}$ described by O'Brien and Sherman (1993) for FPT, which confirms that colostrum feeding time with dams of $1 \mathrm{~d}$ is sufficient. For artificial rearing management, to minimize or even eliminate the mother-kid link, which is established in the first hours after birth (Ramírez et al., 1996), the kids should be removed after parturition. This practice facilitates the acceptance of bottle feeding for the kid, thus improving the success of artificial rearing. Some farmers are still reluctant to remove kids at partum when they are using artificial rearing management, and these kids remain with dams for $5 \mathrm{~d}$ to avoid FPT. The results shown in the present study demonstrate that it is unnecessary to leave kids with dams for more than $24 \mathrm{~h}$ postpartum to avoid FPT. The adaptation from sucking to bottle feeding is more successful with removal of the kid after $24 \mathrm{~h}$ rather than after $5 \mathrm{~d}$ (A. Argüello, unpublished data). When lambs are separated from their mothers $2 \mathrm{~d}$ after birth, they present lower antibodies in the blood than lambs separated at a later stage (after 15 d), possibly because of the stress of separation and the increase in cortisol concentrations (Napolitano et al., 1995). In contrast, Dos Santos et al. (1994) observed no 
Table 3. Immunoglobulin $\mathrm{G}$ in blood serum $(\mathrm{mg} / \mathrm{mL}$, least squares means) in kids

\begin{tabular}{lcccccc}
\hline & \multicolumn{5}{c}{ Age, h } & \\
\cline { 2 - 5 } $\begin{array}{l}\text { Suckling } \\
\text { duration, d }\end{array}$ & 24 & 48 & 72 & 96 & 120 & SEM \\
\hline 1 & $18.3^{\mathrm{a}}$ & $19.9^{\mathrm{a}}$ & $18.6^{\mathrm{a}}$ & $18.1^{\mathrm{a}}$ & $16.2^{\mathrm{b}}$ & 2.3 \\
2 & $17.6^{\mathrm{a}}$ & $14.1^{\mathrm{b}}$ & $14.2^{\mathrm{b}}$ & $14.6^{\mathrm{b}}$ & $15.2^{\mathrm{b}}$ & 2.72 \\
5 & $17.5^{\mathrm{a}}$ & $18.5^{\mathrm{a}}$ & $16.0^{\mathrm{b}}$ & $15.2^{\mathrm{b}}$ & $14.2^{\mathrm{b}}$ & 0.85 \\
\hline
\end{tabular}

${ }^{\mathrm{a}, \mathrm{b}}$ Means within a row with different superscripts differ $(P<0.05)$.

significant differences between kids separated at birth and those raised by dams in terms of IgG and cortisol concentrations between 0 and $19 \mathrm{~h}$ after birth. There is very little information available on goats, although Ramírez et al. (1996) stated that for many species the mother-kid link in ungulated species is established in the first $10 \mathrm{~d}$ after birth. These observations could explain the differences between our observations and those described in Napolitano et al. (1995) in which animals were separated $3 \mathrm{~d}$ after birth; Dos Santos et al. (1994) separated the kids at birth, thus impeding the establishment of the mother-kid relationship.

Tables 2 and 3 show the decrease $(P<0.05)$ in serum $\mathrm{IgG}$ concentrations in kids over a 5 -d period postpartum. The decrease in IgG concentration may be attributed to an overall increase in plasma volume and to the natural degradation of IgG over time (Quigley et al., 1998). Immunoglobulin $\mathrm{G}$ blood serum concentrations peaked between 24 and $48 \mathrm{~h}$ postpartum, and then decreased until the end of the 5 -d period. This evolution of $\operatorname{IgG}$ serum concentrations over time has been observed previously in goat kids (Argüello, 2000).

\section{CONCLUSIONS}

Birth BW and litter size have an important role in FPT; kids from litter sizes of 3 kids or with a low birth BW $(<2.8 \mathrm{~kg})$ have higher possibilities for FPT, and as a result, these animals need special attention at birth. If farmers wish to feed colostrum directly from dams, $24 \mathrm{~h}$ with the dams should be sufficient to develop IgG blood serum concentrations above the FPT threshold.

\section{REFERENCES}

Argüello, A. 2000. Artificial rearing of kids. Colostrum feed, growth, carcass quality and meat quality. PhD Thesis. Las Palmas de Gran Canaria University, Spain.

Argüello, A., N. Castro, S. Alvarez, and J. Capote. 2006. Effects of the number of lactations and litter size on chemical composition and physical characteristics of goat colostrum. Small Rumin. Res. 64:53-59.

Argüello, A., N. Castro, J. Capote, R. Ginés, F. Acosta, and J. L. López. 2003. Effect of refrigeration, freezing-thawing and pasteurization on IgG goat colostrum preservation. Small Rumin. Res. 48:135-139.

Argüello, A., N. Castro, J. Capote, J. W. Tyler, and N. M. Holloway. 2004. Effect of colostrum administration practices on serum IgG in goat kids. Livest. Prod. Sci. 90:235-239.
Bekele, T., E. B. Otesile, and O. B. Kasali. 1992. Influence of passively acquired colostral immunity on neonatal lamb mortality in Ethiopian highland sheep. Small Rumin. Res. 9:209-215.

Castro, N., J. Capote, S. Alvarez, and A. Argüello. 2005. Effects of lyophilized colostrum and different colostrum feeding regimens on passive transfer of immunoglobulin G in Majorera goat kids. J. Dairy Sci. 88:3650-3654.

Castro, N., J. Capote, L. Morales, H. Briggs, and A. Argüello. 2007. The effects of colostrum whey and the addition of milk replacer to colostrum whey on passive transfer of IgG in Majorera goat kids. J. Dairy Sci. 90:2347-2349.

Chen, J. C., C. J. Chang, H. C. Peh, and S. Y. Chen. 1999. Serum protein levels and neonatal growth rate of Nubian goat kids in Taiwan area. Small Rumin. Res. 32:153-160.

Constant, S. B., M. M. Leblanc, E. F. Klapstein, D. E. Beebe, H. M. Leneau, and C. J. Nunier. 1994. Serum immunoglobulin G concentration in goats kids fed colostrum or a colostrum substitute. J. Am. Vet. Med. Assoc. 205:1759-1762.

Dos Santos, G. T., D. A. Bertolini, F. Macedo, I. Prado, and E. Martins. 1994. Variabilidade em imunogloblina G ( $\operatorname{IgG}$ ) no colostro de cabra de primeira ordenha e absorcao intestinal de IgG pelos cabritos recém-nascidos. Arq. Biol. Tecnol. 37:285-292.

Fabelo, F., J. L. López, F. Doreste, and J. F. Capote. 1992. Peso al nacimiento de cabritos de la Agrupación Caprina Canaria (ACC), variedad Majorera y su relación con el peso al destete al ser criados bajo lactancia artificial. Page 170 in Proc. of XVI Actas de las Jornadas Científicas de la Sociedad Española de Ovinotecnia y Caprinotecnia, Pamplona, Spain.

Guerrault, P. 1990. Apport de colostrum: Plusieurs methodes. Chèvre 180:30-31.

Lascelles, A. K. 1979. The immune system on the ruminant mammary gland and its role in the control of mastitis. J. Dairy Sci. 62:154167.

Mancini, G., A. O. Carbonara, and J. F. Heremans. 1965. Immunochemical quantitation of antigens by single radial immunodiffusion. Immunochemistry 2:235-254.

Napolitano, F., V. Marino, G. De Rosa, R. Capparelli, and A. Bordi. 1995. Influence of artificial rearing on behavioral and immune response of lambs. Appl. Anim. Behav. Sci. 45:245-253.

O'Brien, J. P., and D. M. Sherman. 1993. Serum immunoglobulin concentrations of newborn goat kids and subsequent kid survival through weaning. Small Rumin. Res. 11:71-77.

Quigley, J. D. III, J. J. Drewry, and K. R. Martin. 1998. Estimation of plasma volume in Holstein and Jersey calves. J. Dairy Sci. 81:1308-1312.

Rabbani, S., M. Irfan, K. Muhammad, and Z. Q. Ahmed. 1990. Studies on the transfer of maternal immunoglobulins in kids. Arch. Vet. Bucar. 19:53-59.

Ramírez, A., A. Quiles, and M. L. Hevia. 1998. Murciano Granadina kid behaviour at first hours of life. Arch. Zootecn. 47:639-647.

Ramírez, A., A. Quiles, M. L. Hevia, F. Sotillo, and M. C. Ramírez. 1996. Influence of forced contact on the maternal-filial bond in the domestic goat after different periods of postpartum separation. Small Rumin. Res. 23:75-81.

Sherman, D. M., T. D. Arendt, J. M. Gay, and V. A. Maefsky. 1990. Comparing the effects of four colostral preparations on serum Ig levels of newborn kids. Vet. Med. 85:908-913. 